\title{
Leptin inhibits testosterone secretion from adult rat testis in vitro
}

\author{
M Tena-Sempere ${ }^{1}$, L Pinilla ${ }^{1}$, L C González ${ }^{1}$, C Diéguez ${ }^{2}$, \\ F F Casanueva $^{3}$ and E Aguilar ${ }^{1}$
}

${ }^{1}$ Department of Physiology, Faculty of Medicine, University of Córdoba, Córdoba, Spain

${ }^{2}$ Department of Physiology, University of Santiago de Compostela, Santiago de Compostela, Spain

${ }^{3}$ Department of Medicine (Endocrine Section), University of Santiago de Compostela, Santiago de Compostela, Spain

(Requests for offprints should be addressed to E Aguilar, Department of Physiology, Faculty of Medicine, University of Córdoba, 14004 Córdoba, Spain)

\begin{abstract}
Leptin, the product of the $o b$ gene, has emerged recently as a pivotal signal in the regulation of fertility. Although the actions of leptin in the control of reproductive function are thought to be exerted mainly at the hypothalamic level, the potential direct effects of leptin at the pituitary and gonadal level have been poorly characterised. In the present study, we first assessed the ability of leptin to regulate testicular testosterone secretion in vitro. Secondly, we aimed to evaluate whether leptin can modulate basal gonadotrophin and prolactin (PRL) release by incubated hemi-pituitaries from fasted male rats. To attain the first goal, testicular slices from prepubertal and adult rats were incubated with increasing concentrations $\left(10^{-9}-10^{-7} \mathrm{M}\right)$ of recombinant leptin. Assuming that in vitro testicular responsiveness to leptin may be dependent on the background leptin levels, testicular tissue from both fooddeprived and normally-fed animals was used. Furthermore, leptin modulation of stimulated testosterone secretion was evaluated by incubation of testicular samples with different doses of leptin in the presence of $10 \mathrm{IU}$ human chorionic gonadotrophin (hCG). In addition, analysis of leptin actions on pituitary function was carried out using hemi-pituitaries from fasted adult male rats
\end{abstract}

incubated in the presence of increasing concentrations $\left(10^{-9}-10^{-7} \mathrm{M}\right)$ of recombinant leptin. Serum testosterone levels, and basal and hCG-stimulated testosterone secretion by incubated testicular tissue were significantly decreased by fasting in prepubertal and adult male rats. However, a significant reduction in circulating $\mathrm{LH}$ levels was only evident in adult fasted rats. Doses of $10^{-9}-10^{-7} \mathrm{M}$ leptin had no effect on basal or hCGstimulated testosterone secretion by testes from prepubertal rats, regardless of the nutritional state of the donor animal. In contrast, leptin significantly decreased basal and hCG-induced testosterone secretion by testes from fasted and fed adult rats. In addition, $10^{-9} \mathrm{M}$ leptin inhibited LH and FSH secretion by incubated hemi-pituitaries from fasted adult males, whereas, at all doses tested, it was ineffective in modulating PRL release. Our results show that leptin, depending on the state of sexual maturation, is able to inhibit testosterone secretion acting at the testicular level. Furthermore, the present data suggest that the actions of leptin on the reproductive system are complex and are probably carried out at different levels of the hypothalamic-pituitary-gonadal axis.

Journal of Endocrinology (1999) 161, 211-218

\section{Introduction}

The obese gene $(o b)$ product, leptin, is a plasma protein hormone produced in the adipose tissue that plays a key role in the control of food intake and energy expenditure (Zhang et al. 1994, Campfield et al. 1995, Halaas et al. 1995, Pelleymounter et al. 1995, Weigle et al. 1995). Besides its well-known actions in the regulation of body weight, leptin has recently emerged as a metabolic link between nutrition and fertility. Several lines of evidence support this concept. First, it is well established that severe starvation is associated with impaired reproductive function (Warren 1983, Bergendahl et al. 1989, 1991, Rosenbaum \& Leibel 1998) and reduced leptin levels (Nagatani et al. 1998, Vuagnat et al. 1998). Secondly, the absence of biological actions of leptin, due to mutations in the $o b$ gene ( $o b / o b$ mice) or the leptin receptor gene $(d b / d b$ mice), leads to infertility (Jones \& Ainsworth-Harrison 1957, Swerdloff et al. 1976, Batt et al. 1982). Thirdly, treatment of obese $o b / o b$ mice with leptin, but not food restriction, stimulates the reproductive endocrine system and restores fertility in this animal model (Barash et al. 1996, Chehab et al. 1996, Mounzih et al. 1997). Furthermore, leptin administration advances the onset of puberty in normal female mice (Ahima et al. 1997, Chehab et al. 1997). Fourthly, immunoneutralization of endogenous leptin disrupts cyclicity in female rats (Carro et al. 1997b). In addition, leptin has also been implicated as an important factor for signalling the nutritional state to different neuroendocrine systems. In this regard, a role for leptin in the control of pulsatile growth hormone $(\mathrm{GH})$ and luteinizing hormone $(\mathrm{LH})$ secretion has been demonstrated 
recently (Carro et al. 1997a,b, Nagatani et al. 1998, Vuagnat et al. 1998).

The mechanism(s) whereby leptin regulates reproductive function remains to be fully characterised; however the sites for leptin action may include the hypothalamus, the pituitary, and/or the gonads. Compelling evidence points to the hypothalamus as the primary target of leptin (Schwartz et al. 1996, Elmquist et al. 1997). It is noteworthy that the hypothalamus is a key element in the control of food intake and neuroendocrine regulation of reproductive function. Leptin receptors are expressed in specific hypothalamic nuclei (Zamorano et al. 1997, Couce et al. 1997), and the ability of leptin to modulate the expression of several hypothalamic neuropeptides, including LH-releasing hormone (LHRH), somatostatin and neuropeptide Y (Schwartz et al. 1996, Quintela et al. 1997, Yu et al. 1997a,b, Sahu 1998) is well documented. Unlike its actions at the hypothalamic level, the potential direct effects of leptin on pituitary and gonadal function have been poorly characterised. Recent reports have shown that leptin increases basal and LHRH-stimulated LH secretion from hemi-pituitaries of normally-fed male rats (Yu et al. 1997a,b). Studies concerning the direct effects of leptin at the gonadal level have provided evidence for an inhibitory role of leptin on ovarian function (Spicer \& Francisco 1997, 1998, Zachow \& Magoffin 1997). However, to our knowledge, no study analysing the potential direct effects of leptin on testicular function has been reported.

Considering the relevant actions of leptin on the reproductive axis (see above), the present experiments were undertaken to test whether leptin can modulate basal and human chorionic gonadotrophin (hCG)-stimulated in vitro testosterone secretion from the testes of animals under two different nutritional states (normal-feeding and short-term starvation) and at two different ages (prepubertal and adult). In addition, we wanted to evaluate a potential direct regulatory role of leptin on basal gonadotrophin and prolactin (PRL) secretion by hemi-pituitaries from fasted adult male rats. Our data extend previous observations on the role of leptin in the control of pituitary function in the normally-fed rat ( $\mathrm{Yu}$ et al. 1997a,b) as we monitored leptin actions on pituitary function of fasted animals. In this regard, evidence showing that the effects of leptin are dependent on the prevailing metabolic status has been presented previously (Carro et al. 1997a).

\section{Materials and Methods}

\section{Animals and drugs}

Prepubertal (30-day-old) and adult (75- to 90-day-old) Wistar male rats were purchased from Charles River (Criffa, Barcelona, Spain). On arrival, the animals were caged under constant conditions of light $(14 \mathrm{~h}$ of light; lights on at $0700 \mathrm{~h}$ ) and temperature $\left(22^{\circ} \mathrm{C}\right)$, and acclimatised for 3 days with free access to standard laboratory animal food and tap water. Before initiation of experiments, prepubertal and adult animals were divided into groups of approximately similar weight (prepubertal males: $90 \cdot 5 \pm 3 \cdot 6 \mathrm{~g}$; adult males: $252 \cdot 6 \pm 7 \cdot 2 \mathrm{~g}$ ). In fooddeprived groups, the animals had access only to water during the fasting periods: $60 \mathrm{~h}$ in prepubertal rats and $96 \mathrm{~h}$ in adult rats. Control, normally-fed animals received water and standard laboratory food which were available ad libitum. All experimental procedures were approved by the Córdoba University Ethical Committee for animal experimentation and were conducted in accordance with the European Union code for the care and use of experimental animals.

Human recombinant leptin was produced in Saccharomyces cervisae as described elsewhere (Considine et al. 1996), and kindly donated by Eli Lilly (Indianapolis, IN, USA). Highly purified hCG (Profasi HP500) was purchased from Serono (Madrid, Spain). LHRH was obtained from Sigma Chemical Co. (St Louis, MO, USA).

\section{Tissue incubations}

For the analysis of the direct effects of leptin on testosterone secretion, incubation of testicular tissue was carried out as described previously (Tena-Sempere et al. 1997), with minor modifications. Testicular samples were obtained from four experimental groups: (1) prepubertal fasted rats, (2) prepubertal fed rats, (3) adult fasted rats, and (4) adult fed rats. For static incubations, the animals were killed by decapitation and trunk blood was collected for serum hormone measurements. Upon death, the testes were removed immediately, decapsulated, and cut into pieces of approximately equal size (mean weight/piece: $373 \pm 7 \mathrm{mg} /$ piece from prepubertal testes, 2 slices/testis; $368 \pm 5 \mathrm{mg} /$ piece from adult testes, 4 slices/testis). Testicular slices (2 slices/well) were incubated in $2 \mathrm{ml}$ Dulbecco's modified Eagle's medium (DMEM)/F12 medium (1:1; Life Technologies, Grand Island, NY, USA) supplemented with $0.1 \mathrm{~g} / 1$ gentamicin (Biological Industries, Bet-Haemek, Israel) in a Dubnoff shaker $(60$ cycles $/ \mathrm{min})$ at $32{ }^{\circ} \mathrm{C}$ under an atmosphere of $5 \%$ $\mathrm{CO}_{2}-95 \% \mathrm{O}_{2}$. After preincubation for $1 \mathrm{~h}$, the media were replaced with either fresh medium or medium containing increasing doses of leptin $\left(10^{-9}-10^{-7} \mathrm{M}\right)$. In addition, to test the ability of leptin to modulate stimulated testosterone secretion, groups of testicular samples were challenged with different doses of leptin $\left(10^{-9}-10^{-7} \mathrm{M}\right)$ plus hCG (10 IU) or with hCG alone. After 90 and $180 \mathrm{~min}, 100 \mu \mathrm{l}$ aliquots from the incubation media were taken for testosterone measurement, as described below. The levels of testosterone in the media are expressed as normalised values per $\mathrm{g}$ incubated tissue.

Incubation of anterior pituitaries was carried out as described above. Adult fasted males were killed by decapitation, and their anterior pituitaries were immediately 
Table 1 Body weight and serum testosterone and LH levels in prepubertal (30-day-old) and adult (90-day-old) male rats after short-term starvation. The fasting period was $60 \mathrm{~h}$ for prepubertal and $96 \mathrm{~h}$ for adult animals. During these periods, paired control animals had access to standard laboratory food available ad libitum. Values are given as means \pm S.E.M. $(n=25-30$ animals/group)

\begin{tabular}{|c|c|c|c|c|}
\hline & \multicolumn{2}{|l|}{ Prepubertal } & \multicolumn{2}{|l|}{ Adult } \\
\hline & Fed & Fasted & Fed & Fasted \\
\hline Body weight (g) & $101 \cdot 5 \pm 2 \cdot 5$ & $78.9 \pm 1 \cdot 4^{* *}$ & $278 \cdot 5 \pm 8 \cdot 2 \dagger$ & $215 \cdot 6 \pm 6 \cdot 2^{* *} \dagger$ \\
\hline Testosterone (ng/ml) & $1 \cdot 16 \pm 0 \cdot 05$ & $0 \cdot 80 \pm 0 \cdot 04^{* *}$ & $2 \cdot 67 \pm 0 \cdot 12 \dagger$ & $1 \cdot 76 \pm 0 \cdot 10^{* *} \dagger$ \\
\hline LH (ng/ml) & $0 \cdot 30 \pm 0 \cdot 05$ & $0 \cdot 34 \pm 0 \cdot 07$ & $0.57 \pm 0.10 \dagger$ & $0 \cdot 34 \pm 0 \cdot 07^{*}$ \\
\hline
\end{tabular}

removed, dissected free of the posterior pituitary lobe, and halved. Hemi-pituitaries were preincubated for $1 \mathrm{~h}$ in $1 \mathrm{ml}$ gentamicin-supplemented DMEM-F12 medium in a Dubnoff shaker $(60$ cycles $/ \mathrm{min})$ at $37^{\circ} \mathrm{C}$ under an atmosphere of $5 \% \mathrm{CO}_{2}-95 \% \mathrm{O}_{2}$. After preincubation, the media were replaced with either fresh medium or medium containing increasing doses of leptin $\left(10^{-9}-10^{-7} \mathrm{M}\right)$ or LHRH $\left(10^{-6} \mathrm{M}\right)$. After 60 and $120 \mathrm{~min}, 50 \mu \mathrm{l}$ aliquots from the incubation media were taken for $\mathrm{LH}$, folliclestimulating hormone (FSH) and PRL measurements, as described below. Hormonal levels are expressed as normalised values per $10 \mathrm{mg}$ incubated tissue.

\section{Hormone measurements}

Testosterone was measured from diethyl ether extracts of serum and tissue incubation media by RIA using ${ }^{3} \mathrm{H}-$ labelled testosterone as tracer, as described elsewhere (Rodriguez-Padilla et al. 1987). LH, FSH and PRL levels were assayed in incubation media by specific RIAs, using kits supplied by NIDDK (Bethesda, MD, USA). Similarly, serum LH levels from fasted and fed, prepubertal and adult male rats were determined. The results are expressed in terms of LH-reference preparation (RP)-3, FSH-RP-2, and PRL-RP-3.

\section{Statistics}

Data are expressed as means \pm S.E.M. The values were homogeneous and no transformation was carried out. Results from testicular incubations were analysed for statistically significant differences using a two-way ANOVA, followed by Tukey's test. This procedure allows, for each age (prepubertal vs adult) and incubation time-point, the comparison of responses to different doses of leptin and nutritional states, and the interactions between these variables. Similarly, two-way ANOVA was used to assess significant differences in terms of body weight and serum testosterone and $\mathrm{LH}$ levels in the different experimental groups. Finally, data from pituitary incubations were statistically evaluated using a one-way ANOVA, followed by Tukey's test. A value of $P<0 \cdot 05$ was considered significant.

\section{Results}

Assessment of leptin actions on testicular testosterone secretion in vitro was carried out in normally-fed and fasted animals. Food deprivation induced an average reduction in body weight of $21 \%$ and $24 \%$ from normally-fed prepubertal and adult male rats respectively (Table 1 ). Analysis of the endocrine background in the experimental groups was achieved by measuring serum LH and testosterone levels. As shown in Table 1, fasting induced a significant decrease in serum testosterone concentration in both prepubertal and adult male rats. However, a significant reduction in plasma LH levels was only observed in adult animals.

In prepubertal rats, testicular testosterone secretion in vitro was significantly lower $(P \leq 0 \cdot 01)$ than in the corresponding adult groups (normally-fed rats: $3 \cdot 9 \pm 0 \cdot 32$ vs $13.36 \pm 1.34 \mathrm{ng} / \mathrm{ml} / \mathrm{g}$ tissue after $180 \mathrm{~min}$ incubation). Sixty-hour starvation induced a significant decrease in basal and hCG-stimulated in vitro testosterone secretion by testes from prepubertal rats. However, leptin, at all doses tested, failed to modify basal testosterone release and it did not alter the testicular response to hCG in terms of testosterone secretion in fed or food-deprived groups at this age (Fig. 1). As in prepubertal animals, fasting (96 h) of adult males decreased basal and hCG-stimulated testosterone secretion in vitro. However, at this age, leptin was able to inhibit both basal and hCG-induced testosterone release by testes from both fed and starved rats (Fig. 2), although differences in the time-course and dosedependency of this inhibitory effect were noted between groups. In the normally-fed group, at all doses $\left(10^{-9}\right.$ $10^{-7} \mathrm{M}$ ) and both times (90 and $180 \mathrm{~min}$ ) tested, leptin significantly decreased hCG-stimulated testosterone secretion. In addition, in this group basal testosterone release 
BASAL
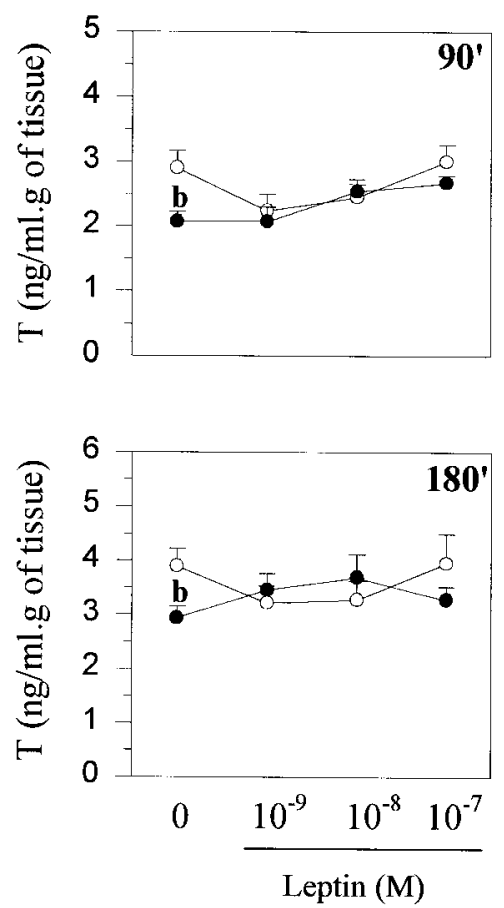

hCG-STIMULATED
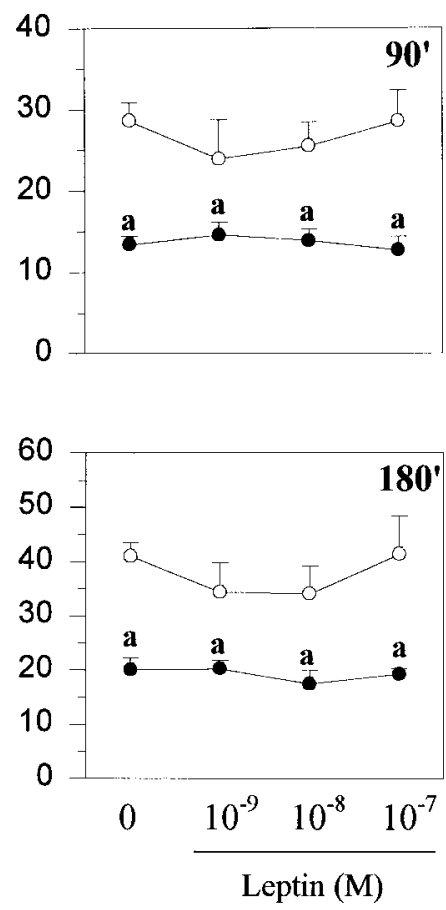

Figure 1 Effects of leptin on in vitro basal (left panels) and hCG-stimulated (right panels) testosterone $(\mathrm{T})$ secretion in prepubertal male rats. Testes from normally-fed $(O)$ and fasted ( ) males were challenged with increasing concentrations of leptin alone (left panels) or leptin plus $10 \mathrm{IU}$ hCG (right panels), and testosterone release to the incubation medium was assessed after 90 and $180 \mathrm{~min}$. Testes incubated in the presence of medium alone (0) served as controls. Values are given as means \pm S.E.M. $(n=12$ samples/group). ${ }^{\mathrm{a}} P<0.01,{ }^{\mathrm{b}} P<0.05$ vs values from corresponding normally-fed groups (two-way ANOVA followed by Tukey's test).

was partially suppressed by leptin, an effect that was observed for all doses $\left(10^{-9}-10^{-7} \mathrm{M}\right)$ after 90 min incubation, but only for the $10^{-9} \mathrm{M}$ dose after incubation for $180 \mathrm{~min}$. In the fasted group, $10^{-9}-10^{-7} \mathrm{M}$ leptin significantly inhibited hCG-stimulated testosterone secretion only after $180 \mathrm{~min}$ incubation. In addition, basal testosterone release by testes from fasted animals was reduced after 90 and $180 \mathrm{~min}$ incubation in the presence of $10^{-9}$ $10^{-7} \mathrm{M}$ leptin, although the decrease induced by $10^{-7} \mathrm{M}$ leptin at 180 min was at the limit of statistical significance.

Besides its actions at the testicular level, the effects of recombinant leptin on basal pituitary function of adult fasted $(96 \mathrm{~h})$ male rats were evaluated. Leptin, in a dose-dependent manner, inhibited gonadotrophin secretion in vitro: $10^{-9} \mathrm{M}$ leptin induced a significant decrease in $\mathrm{LH}$ and FSH release to the medium after 60 (data not shown) and 120 min incubation (Fig. 3), whereas $10^{-8}$ and $10^{-7} \mathrm{M}$ leptin were ineffective. As a positive control, under similar conditions $10^{-6} \mathrm{M}$ LHRH elicited a 3- and 2 -fold increase in LH and FSH secretion respectively. In addition, the effect of leptin on PRL release in vitro was also tested in the same experimental paradigm. Leptin, at all doses tested, failed to change basal PRL secretion by incubated hemi-pituitaries of adult fasted males (Fig. 3).

\section{Discussion}

Our data provide evidence for a direct inhibitory role of leptin in the control of basal and stimulated testicular testosterone secretion in adult rats. This inhibitory action appeared independent of the prevailing nutritional state, and was not observed in prepubertal rat testes. In addition, leptin, in a dose-dependent manner, selectively inhibited in vitro gonadotrophin secretion by hemi-pituitaries from adult fasted males. Several reasons prompted us to assess whether potential leptin effects depend on the age of the animal or on background leptin levels. First, testicular steroid secretion changes with age (Moger 1977, Corpéchot et al. 1981), and it is known that adult-type Leydig cells, responsible for testosterone production postnatally, show different developmental stages during 
BASAL
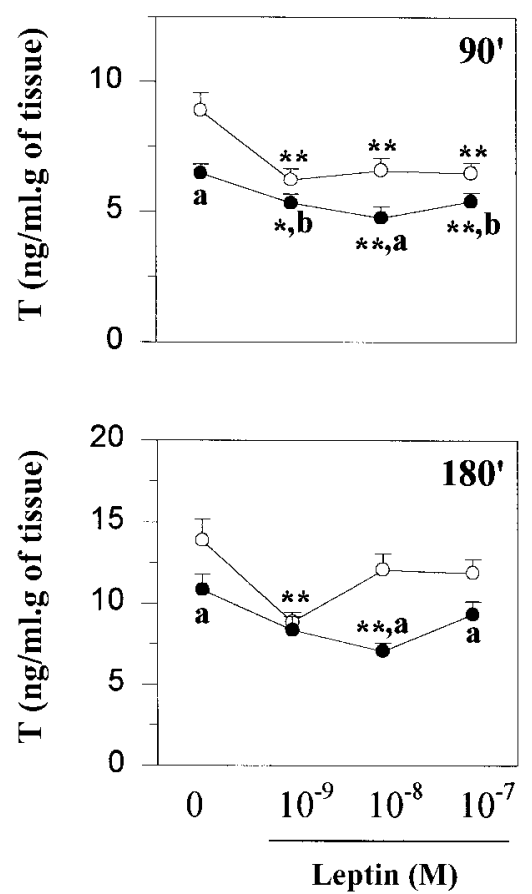

\section{hCG-STIMULATED}
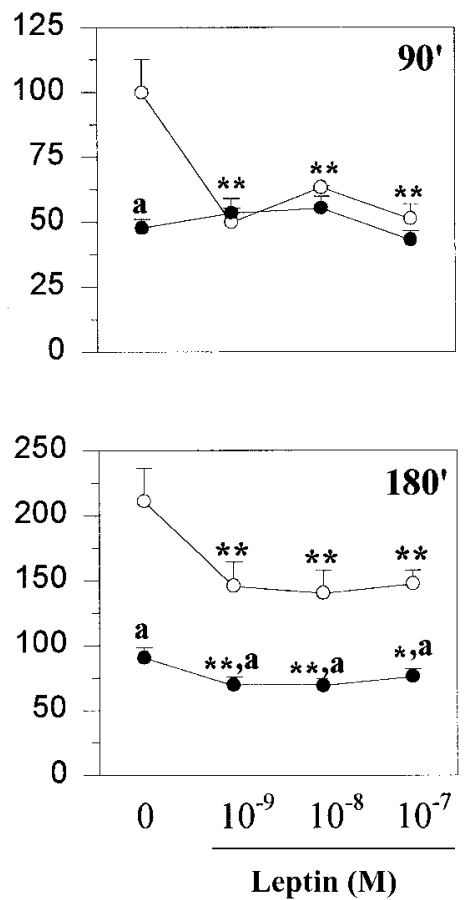

Figure 2 Effects of leptin on in vitro basal (left panels) and hCG-stimulated (right panels) testosterone $(\mathrm{T})$ secretion in adult male rats. Testes from normally-fed $(\bigcirc)$ and fasted $(\bullet)$ males were challenged with increasing concentrations of leptin alone (left panels) or leptin plus $10 \mathrm{IU}$ hCG (right panels), and testosterone release to the incubation medium was assessed after 90 and $180 \mathrm{~min}$. Testes incubated in the presence of medium alone (0) served as controls. Values are given as means \pm S.E.M. ( $n=12$ samples/group). ${ }^{*} P<0 \cdot 05,{ }^{* *} P<0 \cdot 01$ vs values from corresponding controls $(0) ;{ }^{a} P<0 \cdot 01,{ }^{b} P<0 \cdot 05$ vs values from corresponding normally-fed groups (two-way ANOVA followed by Tukey's test).

pubertal and postpubertal maturation (Shan \& Hardy 1992). Secondly, short-term starvation has been shown to induce a decrease in endogenous leptin levels in both male and female rats (Nagatani et al. 1998, Vaugnat et al. 1998) and evidence for the modulatory role of the metabolic state on the actions of leptin in the neuroendocrine control has been reported previously (Carro et al. 1997a).

Overall, an inhibitory action of leptin on in vitro testosterone secretion was observed in both normally-fed and fasted adult animals. However, differences in the timecourse and dose-dependency of the reported inhibitory actions of leptin were noted depending on the nutritional state. In the fed group, leptin, at all doses tested, decreased basal and hCG-stimulated testosterone secretion, although the effect on basal testosterone release was only evident after 90 min incubation. In food-deprived animals, hCGstimulated testosterone secretion was inhibited by $10^{-9}$ $10^{-7} \mathrm{M}$ leptin only after $180 \mathrm{~min}$ incubation, whereas basal testosterone release decreased after 90 and $180 \mathrm{~min}$ incubation in the presence of $10^{-9}-10^{-7} \mathrm{M}$ leptin. Inter- estingly, the effects of leptin at the testicular level appear to be opposite to those reported for the systemic administration of leptin in ob/ob male mice (Barash et al. 1996). A similar anomaly has been described for the female, where leptin administration increased serum $\mathrm{LH}$ and ovarian weight in female $o b / o b$ mice, but it had a direct inhibitory action upon ovarian steroidogenesis (Zachow \& Magoffin 1997, Spicer \& Francisco 1998). Taken together, the current data point to a complex mode of action of leptin at multiple sites of the hypothalamic-pituitary-gonadal axis in its control of reproductive function.

It is noteworthy that the reported inhibitory effects of leptin appeared dependent on the state of sexual maturation as they were seen in adult but not in prepubertal animals. It is tempting to speculate that this phenomenon may represent a protective mechanism to ensure proper testosterone production around puberty, a period when a rise in circulating leptin levels occurs in humans and rodents (Chehab et al. 1997, García-Mayor et al. 1997). Conclusions regarding the mechanism(s) for the inhibitory 

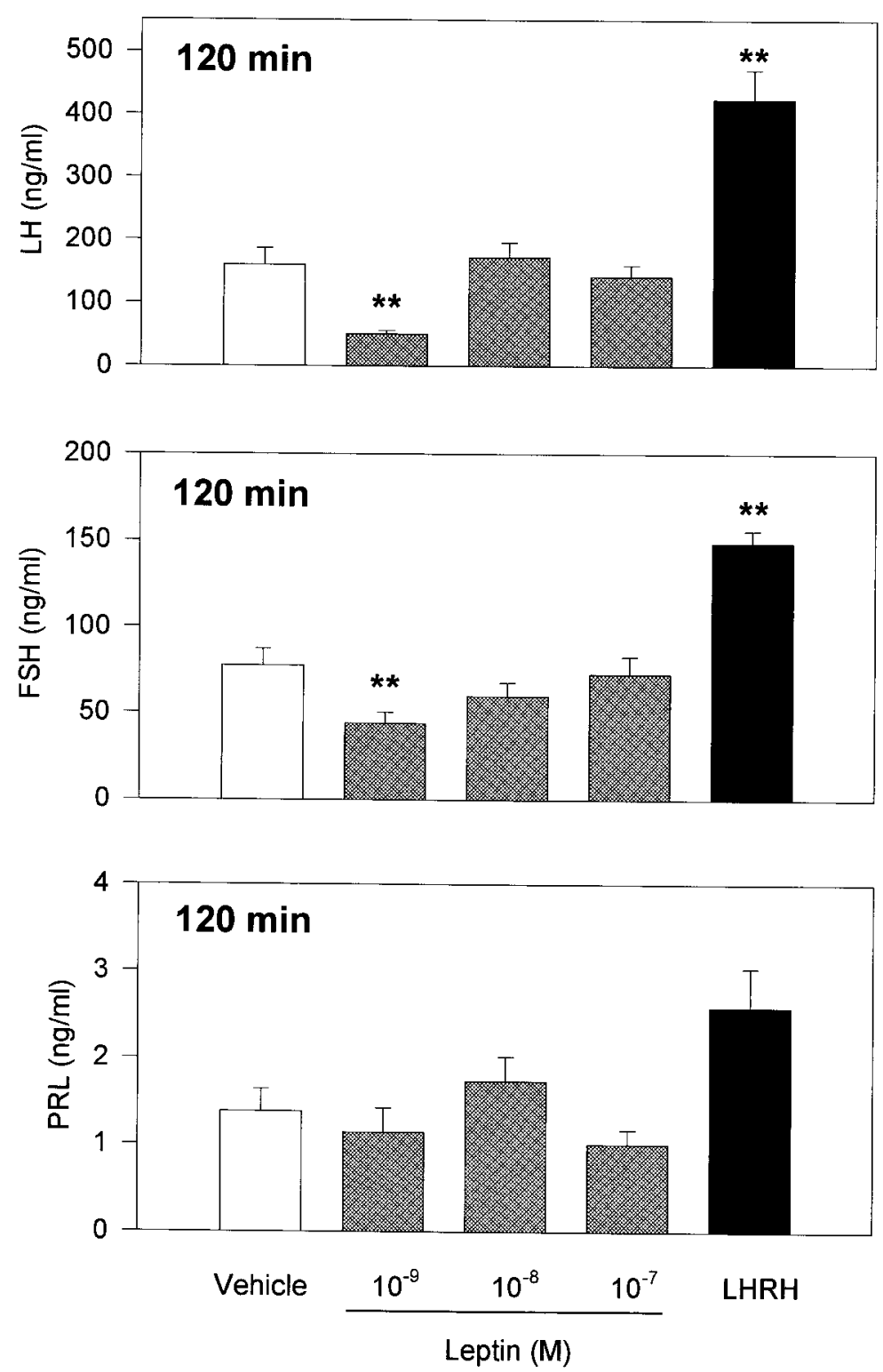

Figure 3 Effects of leptin on in vitro basal LH, FSH, and PRL secretion in adult fasted male rats. Hemi-pituitaries from adult fasted animals were incubated in the presence of increasing concentrations of leptin $\left(10^{-9}-10^{-7} \mathrm{M}\right)$ or $\mathrm{LHRH}\left(10^{-6} \mathrm{M}\right)$. As the pattern of hormone release was similar after 60 and 120 min incubation, only data from the latter time-point are presented. Values are given as means \pm S.E.M. ( 10 samples per group). ${ }^{*} P<0 \cdot 01$ vs control samples incubated in the presence of DMEM alone (one-way ANOVA followed by Tukey's test).

actions of leptin cannot be drawn on the basis of the present data. Interestingly, a recent report showed that murine recombinant leptin attenuated the ability of insulin-like growth factor (IGF)-I to elicit testosterone release from isolated rat Leydig cells but failed to modify basal and hCG-stimulated testosterone production (Valenti et al. 1998). Although clear-cut differences in the experimental approaches exist, our present data using whole testicular tissue open up the possibility that, at least partially, the actions of leptin are due to its ability to modulate the paracrine network involved in the control of basal and stimulated testicular steroidogenesis.

In our animal model, fasting of prepubertal and adult rats induced a significant decrease in serum testosterone 
levels as well as in the capacity of testes to secrete testosterone in vitro, under both basal and hCG-stimulated conditions. However, a concomitant reduction in circulating LH levels was only evident in adult fasted rats. The possibility of age-related changes in the pattern of gonadotrophin response to fasting cannot be ruled out. However, speculation on this topic is hampered by the limited sensitivity of conventional RIAs for LH measurement. Indeed, variations in the magnitude of the decrease in LH after fasting in adult rats have been reported depending on the assay method used (Perheentupa et al. 1995).

In a previous report, leptin was demonstrated to stimulate $\mathrm{LH}$ and FSH secretion by incubated hemi-pituitaries from adult, normally-fed male rats (Yu et al. 1997a). We aimed to extend this observation, and determine whether the effects of leptin at the pituitary level in the control of gonadotrophin secretion can be modulated by the prevailing nutritional state. Basal LH and FSH secretion by hemi-pituitaries from adult fasted males was significantly inhibited by $10^{-9} \mathrm{M}$ leptin, whereas basal PRL secretion was not modified. Surprisingly, in our incubation system, $10^{-8}$ and $10^{-7} \mathrm{M}$ leptin did not change basal gonadotrophin release, suggesting that the inhibitory actions of leptin on LH and FSH secretion are carried out in a narrow range of doses. In addition, when compared with data from Yu and co-workers $(1997 a, b)$, our results suggest that the effects of leptin at the pituitary level on the control of gonadotrophin secretion depend on the nutritional background. The mechanism(s) underlying such a phenomenon is unclear but may involve the presence of different leptin receptor isoforms. Two major putative isoforms of leptin receptor (termed leptin- $\mathrm{R}_{\mathrm{L}}$ and leptin- $\mathrm{R}_{\mathrm{S}}$ ), with different biological roles, have been identified (Tartaglia 1997), and the balance of their expression in rat brain is altered by fasting (Bennett et al. 1998). Thus, it is tempting to speculate that the reported switch in the effect of leptin in vitro on $\mathrm{LH}$ and FSH release may depend on the differential expression of leptin receptor isoforms under different nutritional states.

In conclusion, our results show that leptin is able to inhibit in vitro basal and hCG-stimulated testosterone secretion by adult rat testes. This effect is not dependent on the prevailing nutritional state, and is not observed in prepubertal animals. In addition, leptin, in a dosedependent manner, selectively inhibits in vitro gonadotrophin secretion by hemi-pituitaries from adult fasted males. Overall, our present data suggest that the actions of leptin on the reproductive system are probably carried out at different levels of the hypothalamic-pituitary-testicular axis.

\section{Acknowledgements}

This work was supported by grants from DGICYT (Spain). Materials for the determination of LH, FSH, and
PRL were supplied by NIDDK's National Hormone and Pituitary Program and A F Parlow (Bethesda, MD, USA). Leptin was a generous gift from Eli Lilly (Indianapolis, IN, USA). The authors are indebted to Rocío Campón and Inmaculada Aguilar for their excellent technical assistance.

\section{References}

Ahima RS, Dushay J, Flier SN, Prabakaran D \& Flier JS 1997 Leptin accelerates the onset of puberty in normal female mice. Journal of Clinical Investigation 99 391-395.

Barash IA, Cheung CC, Weigle DS, Ren H, Kabigting ED, Kuijper JL, Clifton DK \& Steiner RA 1996 Leptin is a metabolic signal to the reproductive system. Endocrinology 137 3144-3147.

Batt R, Everard D, Gillies G, Wilkinson M, Wilson C \& Yoe T 1982 Investigation into the hypogonadism of the obese mouse (genotype $\mathrm{ob} / \mathrm{ob})$. Journal of Reproduction and Fertility 64 363-371.

Bennett PA, Lindell K, Karlsson C, Robinson ICAF, Carlsson LMS \& Carlsson B 1998 Differential expression and regulation of leptin receptor isoforms in the rat brain: effects of fasting and oestrogen. Neuroendocrinology 67 29-36.

Bergendahl M, Perheentupa A \& Huhtaniemi I 1989 Effect of short-term starvation on reproductive hormone gene expression, secretion and receptor levels in male rats. Journal of Endocrinology 121 409-417.

Bergendahl M, Perheentupa A \& Huhtaniemi I 1991 Starvationinduced suppression of pituitary-testicular function in rats is reversed by pulsatile gonadotropin-releasing hormone substitution. Biology of Reproduction 44 413-419.

Campfield LA, Smith FJ, Guisez Y, Devos R \& Burn P 1995 Recombinant mouse $\mathrm{OB}$ protein: evidence for a peripheral signal linking adiposity and central neural networks. Science 269 546-549.

Carro E, Señaris R, Considine RV, Casanueva FF \& Dieguez C 1997 a Regulation of in vivo growth hormone secretion by leptin. Endocrinology 138 2203-2206.

Carro E, Pinilla L, Seoane LM, Considine RV, Aguilar E, Casanueva FF \& Dieguez C $1997 b$ Influence of the endogenous leptin tone on the estrous cycle and LH pulsatility in female rats. Neuroendocrinology 66 375-377.

Chehab FF, Lim ME \& Lu R 1996 Correction of the sterility defect in homozygous obese female mice by treatment with the human recombinant leptin. Nature Genetics 12 318-320.

Chehab FF, Mounzih K, Lu R \& Lim ME 1997 Early onset of reproductive function in normal female mice treated with leptin. Science 275 88-90.

Considine RV, Sinha MK, Heiman ML, Kriauciunas A, Stephens TW, Nyce MR, Ohannesian JP, Marco CC, McKee LJ, Bauer TL \& Caro JF 1996 Serum immunoreactive-leptin concentrations in normal-weight and obese humans. New England Journal of Medicine $334292-295$.

Corpéchot C, Baulieu EE \& Robel P 1981 Testosterone, dihydrotestosterone and androstanediols in plasma, testes and prostates of rats during development. Acta Endocrinologica 96 127-135.

Couce ME, Bruguera B, Parisi JE, Jensen MD \& Lloyd RV 1997 Localization of leptin receptor in the human brain. Neuroendocrinology 66 145-150.

Elmquist JK, Ahima RS, Maratos-Flier E, Flier JS \& Saper CB 1997 Leptin activates neurons in ventrobasal hypothalamus and brainstem. Endocrinology 138 839-842.

García-Mayor RV, Andrade MA, Rios M, Lage M, Dieguez C \& Casanueva FF 1997 Serum leptin levels in normal children: relationship to age, gender, body mass index, pituitary-gonadal hormones, and pubertal stage. Journal of Clinical Endocrinology and Metabolism 82 2849-2855. 
Halaas JL, Gajiwala KS, Maffei M, Cohen SL, Chait BT, Rabinowitz D, Lallone RL, Burley SK \& Friedman JM 1995 Weight-reducing effects of the plasma proteins encoded by the obese gene. Science $269543-546$.

Jones N \& Ainsworth-Harrison G 1957 Genetically determined obesity and sterility in the mouse. Studies in Fertility 9 51-64.

Moger WH 1977 Serum $5 \alpha$-androstane, $3 \alpha, 17 \beta$-diol, androstene and testosterone concentrations in the male rat. Influence of age and gonadotropin stimulation. Endocrinology 100 1027-1032.

Mounzih K, Lu R \& Chehab FF 1997 Leptin treatment rescues the sterility of genetically obese ob/ob males. Endocrinology 138 1190-1193.

Nagatani S, Guthikonda P, Thompson RC, Tsukamura H, Maeda K-I \& Foster DL 1998 Evidence for GnRH regulation by leptin: leptin administration prevents reduced pulsatile LH secretion during fasting. Neuroendocrinology 67 370-376.

Pelleymounter MA, Cullen MJ, Baker MB, Hecht R, Winters D, Boone T \& Collins F 1995 Effects of the obese gene product on body weight regulation in ob/ob mice. Science $269540-543$.

Perheentupa A, Bergendahl M \& Huhtaniemi I 1995 Modulation of gonadotropin secretion at the pituitary level by testosterone in gonadotropin-releasing hormone-treated male rats during food deprivation. Biology of Reproduction 52 808-813.

Quintela M, Señaris R, Heiman ML, Casanueva FF \& Dieguez C 1997 Leptin inhibits in vitro hypothalamic somatostatin secretion and somatostatin mRNA levels. Endocrinology 138 5641-5644.

Rodriguez-Padilla M, Bellido C, Pinilla L \& Aguilar E 1987 Secretion of LH in spontaneously hypertensive rats. Journal of Endocrinology $113255-260$.

Rosenbaum M \& Leibel RL 1998 Leptin: a molecule integrating somatic energy stores, energy expenditure and fertility. Trends in Endocrinology and Metabolism 9 117-123.

Sahu A 1998 Evidence suggesting that galanin (GAL), melaninconcentrating hormone $(\mathrm{MCH})$, neurotensin $(\mathrm{NT})$, proopiomelanocortin (POMC) and neuropeptide $\mathrm{Y}$ (NPY) are targets of leptin signaling in the hypothalamus. Endocrinology 139 795-798.

Schwartz MW, Seeley RJ, Campfield A, Burn P \& Baskin DG 1996 Identification of targets of leptin action in rat hypothalamus. Journal of Clinical Investigation 98 1101-1106.

Shan L-X \& Hardy MP 1992 Developmental changes in levels of luteinizing hormone receptor and androgen receptor in rat Leydig cells. Endocrinology 131 1107-1114.

Spicer LJ \& Francisco CC 1997 The adipose obese gene product, leptin: evidence of a direct inhibitory role in ovarian function. Endocrinology 138 3374-3379.

Spicer LJ \& Francisco CC 1998 Adipose obese gene product, leptin, inhibits bovine ovarian thecal cell steroidogenesis. Biology of Reproduction 58 207-212.
Swerdloff RS, Batt RA \& Bray GA 1976 Reproductive hormonal function in the genetically obese (ob/ob) mouse. Endocrinology 98 1359-1364.

Tartaglia LA 1997 The leptin receptor. Journal of Biological Chemistry 272 6093-6096.

Tena-Sempere M, Rannikko A, Kero J, Zhang F-P \& Huhtaniemi IT 1997 Molecular mechanisms of reappearance of luteinizing hormone receptor expression and function in rat testis after selective Leydig cell destruction by ethylene dimethane sulfonate. Endocrinology 138 3340-3348.

Valenti S, Cesarone A, Foppiani L, Giordano G \& Giusti M 1998 Effect of recombinant murine leptin administration on percoll-purified rat Leydig cells. IV European Congress of Endocrinology OR5-6 (Abstract). Bristol: BioScientifica.

Vaugnat BAM, Pierroz DD, Lalaoui M, Englaro P, Pralong FP, Blum WF \& Aubert ML 1998 Evidence for a leptin-neuropeptide $\mathrm{Y}$ axis for the regulation of growth hormone secretion in the rat. Neuroendocrinology 67 291-300.

Warren MP 1983 Effects of undernutrition on reproductive function in the human. Endocrine Reviews 4 363-377.

Weigle D, Bukowski T, Foster D, Holderman S, Kramer J, Lasser G, Lofton-Day C, Prunkard D, Raymond C \& Kuijper J 1995

Recombinant $o b$ protein reduces feeding and body weight in the ob/ob mouse. Journal of Clinical Investigation 96 2065-2070.

Yu WH, Kimura M, Walczewska A, Karanth S \& McCann SM 1997a Role of leptin in hypothalamic-pituitary function. Proceedings of the National Academy of Sciences of the USA 94 1023-1028.

Yu WH, Walczewska A, Karanth S \& McCann SM $1997 b$ Nitric oxide mediates leptin-induced luteinizing hormone-releasing hormone (LHRH) and LHRH and leptin-induced $\mathrm{LH}$ release from the pituitary gland. Endocrinology 138 5055-5058.

Zachow RJ \& Magoffin DA 1997 Direct intraovarian effects of leptin: impairment of the synergistic action of insulin-like growth factor-I on follicle-stimulating hormone-dependent estradiol-17 $\beta$ production by rat ovarian granulosa cells. Endocrinology 138 847-850.

Zamorano PL, Mahesh VB, De Sevilla LM, Chorich LP, Bhat GK \& Brann DW 1997 Expression and localization of the leptin receptor in endocrine and neuroendocrine tissues of the rat. Neuroendocrinology 65 223-228.

Zhang Y, Proenca R, Maffei M, Barone M, Leopold L \& Friedman JM 1994 Positional cloning of the mouse obese gene and its human homologue. Nature 372 425-432.

Received 16 September 1998 